\title{
Research Note: Athletic Graduation Rates and Simpson’s Paradox
}

\author{
Victor A. Matheson
}

March 2005

\section{COLLEGE OF THE HOLY CROSS, DEPARTMENT OF ECONOMICS \\ FACULTY RESEARCH SERIES, WORKING PAPER NO. 05-06*}

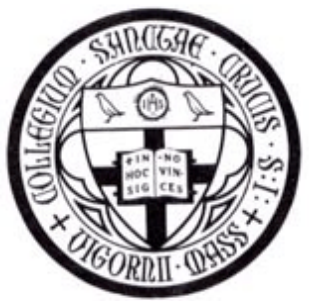

Department of Economics

College of the Holy Cross

Box 45A

Worcester, Massachusetts 01610

(508) 793-3362 (phone)

(508) 793-3710 (fax)

http://www.holycross.edu/departments/economics/website

*All papers in the Holy Cross Working Paper Series should be considered draft versions subject to future revision. Comments and suggestions are welcome. 


\title{
Research Note: Athletic Graduation Rates and Simpson’s Paradox
}

\author{
Victor A. Matheson ${ }^{\dagger}$ \\ College of the Holy Cross
}

March 2005

\begin{abstract}
Graduation rates for male athletes overall as well as men's football and basketball players lag behind those of male non-athletes at Division I colleges and universities. Scholarship athletes, however, are much more likely to be drawn from racial and ethnic groups with lower average graduation rates. After accounting for differences in racial composition, graduation rates for male athletes overall as well football players match or exceed those of their peers, and racial differences account for over one-quarter of the shortfall in men's basketball graduation rates. This is a classic example of Simpson's Paradox.
\end{abstract}

JEL Classification Codes: L83 - Sports; Gambling; Recreation; Tourism

Keywords: college sports, sports economics, graduation rates, higher education

${ }^{\dagger}$ Victor A. Matheson, Department of Economics, Box 157A, College of the Holy Cross, Worcester, MA 01610-2395, 508-793-2649 (phone), 508-793-3710 (fax), vmatheso@holycross.edu 
Research Note: Athletic Graduation Rates and Simpson’s Paradox

\section{INTRODUCTION}

It is a widely held notion that big-time college athletics is incompatible with academics, particularly in the money-making sports such as football and men's basketball. Athletes, it is said, get preferential treatment in admissions, housing, and amenities. They take easier (and sometimes academically worthless) courses, are graded less severely, and perform worse than their peers in the classroom despite the availability of special academic services, such as private tutoring, available only to athletes. (See Sperber (2000), Shulman and Bowen (2001), and Bowen and Levin (2003) and among others.)

The simplest and most common statistic used to justify this conception of academic underperformance is the graduation rate for athletes. The popular media frequently runs stories regarding low graduation rate among top college teams. For example, much was made of the fact that two-thirds of the men's basketball teams participating in the 2005 National Collegiate Athletic Association (NCAA) men’s Division I basketball championship tournament had graduation rates of less than $50 \%$ and that several teams had graduated none of their recent African-American players. Only 4 of the 64 teams had graduated all of their players over the past year. The question remains, however, does this anecdotal evidence add up to a blanket condemnation of college athletics at the top American colleges and universities.

Several researchers examined the topic of graduation rates and athletic success beginning with Tucker (1992) who concludes that success on the field spills over into higher graduation rates for the student body as a whole. Rishe (2003) and Tucker (2004a, 2004b) both examine the 
effects of on-field success on student-athlete graduation rates and find, contrary to the perceived wisdom, that athlete graduate at higher rates than students overall. Rishe, however, finds that increased athletic success tends to reduce athletic graduation rates. This short research note extends the previous research by specifically incorporating the racial mix of student athletes compared to the general student body into graduation rates and suggests that the situation is much less dire than the media reports and popular perception would suggest.

\section{GRADUATION RATES: THE EVIDENCE}

The 2004 NCAA Graduation-Rate Report provides detailed, institution-by-institution information regarding the 6-year graduation rates for both the student body as a whole and for scholarship athletes for the incoming class of 1997-98. Scholarship athletes are athletes receiving financial aid based solely on their playing ability rather than upon other factors such as financial need or academic qualifications. The six-year graduation rate is the percent of students who graduate from an institution within six years of first entering the school. As noted by the NCAA, "graduation rates are affected by a number of factors: some students may work part-time and need more than six years to graduate, some may leave school for a year or two to work or travel, some may transfer to another college or university, or some may be dismissed for academic deficiencies.” (NCAA, 2004)

Graduation rates are further broken down by type of institution, gender, race/ethnicity, and sport.

This paper will focus on graduation rates at Division I schools. Division I is the top level of collegiate competition at American colleges and universities. Division I schools generally have the largest enrollments and most extensive athletic programs and also receive the lion's share of media attention and fan support. In addition, Division I schools offer the most athletic scholarships. In fact, Division III schools are prohibited entirely from offering athletic based 
financial aid although athletes at these institutions may still obtain preferential treatment in admissions or receive special academic attention.

At first glance, graduation rates both support and contradict the critics of college athletics. For example, as noted by Rishe (2003), the academic/athletic divide appears to affect only male athletes. The graduation rate for female scholarship athletes at Division I schools is $69 \%$, well above the $62 \%$ graduation rate for their non-athlete peers. Focusing on male Division I scholarship athletes, Table 1 shows the six-year graduation rates by race or ethnicity for all male students, all male scholarship athletes, and specifically for football players and men’s basketball players. In addition, the proportion of each group represented by each race/ethnicity is shown. Finally, the hypothesis that the graduation rates for each race/ethnicity within each sport, as well as male athletes overall, is the same as the graduation rate for the that race/ethnic group for the population as whole is tested against the alternative hypothesis that the two graduation rates are different. The resulting z-statistics are shown in the final column of each sport.

As shown in the totals row for each sport, male scholarship athletes graduate at a lower clip than male students as a whole, $55 \%$ to $57 \%$, a statistically significant result at the $1 \%$ level. Athletes in football also graduate at a statistically significantly lower 55\% rate (at the $5 \%$ level) while male basketball players fare worst of all with a mere $44 \%$ graduation rate (statistically significant at the $1 \%$ level.) A cursory look at the figures seems to confirm the critics' concerns of academic underperformance by athletes, especially in the revenue sports.

A closer look, however, reveals a much different result. It is crucial to notice that among students overall, blacks fare much worse in graduation rates with only $36 \%$ of African-American males graduating from college within six years of enrollment. Conversely, American students of 
Asian and Pacific Island descent graduate at a 65\% rate, well above the national average. These two ethnic groups are represented disproportionally on athletic rosters. While blacks make up only $9.3 \%$ of the student body as a whole, they represent $26.8 \%$ of male athletes as a whole and 48.8\% and 54.3\% of football and basketball players, respectively. Asian and Pacific Islander Americans, on the other hand, who make up 7.3\% of the general student population, represent only $1.5 \%$ of all athletes, and no Asian Americans were on scholarship in Basketball during this time period.

In fact, while the graduation rate for athletes as a whole is lower than for non-athletes, the group with the biggest difference in graduation rates between athletes and non-athletes is black male athletes who graduate at a much higher rate than black male students as a whole, $48 \%$ to 36\%. Even more dramatically, football players graduate at a lower rate than regular students, $55 \%$ to $57 \%$, a difference statistically significant at the $5 \%$ level. However, both white and black football players graduate at higher rate than their non-athlete peers (65\% to 60\%) and (48\% to 36\%) respectively. The only reason that football graduation rates are lower than average graduation rates is that scholarship football players are predominantly black, and black students graduate at much lower rates than other students. If football players graduated at the same rates as observed for each race/ethnicity, but scholarships were divided among different races in the same proportions as the rest of the population, the graduation rate for football players would be nearly $60 \%$, higher than the graduation rate for male students overall by a statistically significant margin (at the 5\% level). This is a classic example of Simpson's Paradox, which is the reversal of results caused by the combination of two or more dissimilar groups In fact, Simpson’s Paradox may even explain the lower graduation rates for Asian/Pacific Islander football players 
since the distribution of area of origin may be different for Asian-American scholarship football players than for Asian-Americans in the student body as a whole (e.g. Pacific Islander vs. Chinese- or Japanese-American.)

Similarly, if all male athletes graduated at the same rates as observed for each race/ethnicity, but scholarships were divided among different races in the same proportions as the rest of the population, the graduation rate for male athletes would rise to just below 57\%, a figure statistically indifferent from the graduation rate of students overall.

Basketball does not fare quite as well, but again the difference in ethnic backgrounds between men's basketball players and the average student explains a large portion of the shortfall in graduation rates. If men's basketball players graduated at the same rates as observed for each race/ethnicity, but scholarships were divided among different races in the same proportions as the rest of the population, the graduation rate for male basketball players would rise from $44 \%$ to $48 \%$ accounting for over one-quarter of the shortfall in the graduation rate between basketball players and that of the student body as a whole.

African-American basketball players, arguably the most vulnerable segment of the population, fare quite well with a graduation rate of $44 \%$. Of course, it's not that a $44 \%$ graduation rate is an admirable achievement, but compared with a graduation rate of $36 \%$ for non-athlete black males, it is a statistically significant improvement. Apparently it’s not that big time college athletics fails black athletes but rather that the higher education system as a whole fails black students in general. Indeed, if graduation rates are affected by academic deficiencies and financial difficulties, then athletic departments' systems of private tutoring as well as the athletic scholarships themselves may provide important resources to black athletes who tend to 
be poorer and come from worse educational backgrounds than their college classmates.

\section{CONCLUSIONS}

Graduation rates for male athletes overall as well as the graduation rates for football and men’s basketball players lag behind those of male non-athletes at Division I colleges and universities. Scholarship athletes, however, are much more likely to be drawn from the black community, which has a much lower graduation rate than other racial and ethnic groups. After accounting for differences in racial composition, graduation rates for male athletes overall as well football players exceed those of their peers. This is a classic example of the phenomenon known as Simpson's Paradox. Graduation rates for men's basketball players still trail those of non-athletes, but differences in the average racial makeup of the typical basketball team accounts for one-quarter to one-third of the shortfall. In short, care must be taken in using athletic graduation rates as a measure of the academic success of scholarship athletes. 


\section{REFERENCES}

Bowen, W. G. and Levin, S. A. (2003). Reclaiming the Game. Princeton, NJ: Princeton University Press.

National Collegiate Athletic Association. (2004). 2004 Graduation-Rates Report. http://www.ncaa.org/grad_rates/

Rishe, P. J. (2003) A reexamination of how athletic success impacts graduation rates: comparing student-athletes to all other undergraduates. American Journal of Economics and Sociology, 62(2), 407-421.

Shulman, J. L., and Bowen, W. G. (2001). The Game of Life. Princeton, NJ: Princeton University Press.

Sperber, M., (2000). Beer and Circus. New York: Henry Holt and Company.

Tucker, I. B. (2004a). A reexamination of the effect of big-time football and basketball success on graduation rates and alumni giving rates. Economics of Education Review, 23(4), 655661.

Tucker I. B. (2004b) The impact of NCAA reforms on the relationship between big-time football players’ graduation rates. Working paper. 
Table 1: Graduation rates for students and athletes

\begin{tabular}{|c|c|c|c|c|c|c|c|c|}
\hline \multirow[b]{2}{*}{$\frac{\text { Race/Eth. }}{\text { American }}$} & \multicolumn{4}{|c|}{ All male students } & \multicolumn{4}{|c|}{ All male athletes } \\
\hline & $\underline{\text { Number }}$ & $\underline{\text { Grad-rate }}$ & $\underline{\text { Proportion }}$ & & $\underline{\text { Number }}$ & $\underline{\text { Grad-rate }}$ & Proportion & z-stat \\
\hline Indian/AN & 1,595 & $41 \%$ & $0.6 \%$ & & 27 & $37 \%$ & $0.3 \%$ & -0.416 \\
\hline Asian/PI & 19,549 & $65 \%$ & $7.3 \%$ & & 141 & $56 \%$ & $1.5 \%$ & -2.225 \\
\hline Black & 25,081 & $36 \%$ & $9.3 \%$ & & 2,525 & $48 \%$ & $26.8 \%$ & $11.899^{* *}$ \\
\hline Hispanic & 15,374 & $47 \%$ & $5.7 \%$ & & 270 & $44 \%$ & $2.9 \%$ & -0.955 \\
\hline White & 193,890 & $60 \%$ & $72.0 \%$ & & 5,714 & $59 \%$ & $60.6 \%$ & -1.527 \\
\hline NR Alien & 5,864 & $59 \%$ & $2.2 \%$ & & 485 & $59 \%$ & $5.1 \%$ & -0.015 \\
\hline Other & $\underline{7,824}$ & $\underline{56 \%}$ & $\underline{2.9 \%}$ & & $\underline{274}$ & $\underline{50 \%}$ & $\underline{2.9 \%}$ & $\underline{-1.964}$ \\
\hline \multirow[t]{2}{*}{$\overline{\text { Total }}$} & 269,177 & $57 \%$ & $100.0 \%$ & & $9, \overline{436}$ & $\overline{55 \%}$ & $10 \overline{0 \%}$ & $-3.621^{*}$ \\
\hline & \multicolumn{4}{|c|}{ Men's Basketball } & Football & & & \\
\hline$\frac{\text { Race/Eth. }}{\text { American }}$ & $\underline{\text { Number }}$ & $\underline{\text { Grad-rate }}$ & Proportion & z-stat & $\underline{\text { Number }}$ & $\underline{\text { Grad-rate }}$ & Proportion & z-stat \\
\hline Indian/AN & 3 & $33 \%$ & $0.4 \%$ & -0.270 & 10 & $30 \%$ & $0.3 \%$ & -0.705 \\
\hline Asian/PI & 0 & n.a. & $0.0 \%$ & n.a. & 56 & $48 \%$ & $1.7 \%$ & $-2.629^{* *}$ \\
\hline Black & 445 & $42 \%$ & $54.3 \%$ & $2.622^{* *}$ & 1,631 & $48 \%$ & $48.8 \%$ & $9.748^{* *}$ \\
\hline Hispanic & 15 & $33 \%$ & $1.8 \%$ & -1.060 & 58 & $38 \%$ & $1.7 \%$ & -1.382 \\
\hline White & 279 & $48 \%$ & $34.0 \%$ & $-4.078^{* *}$ & 1,468 & $65 \%$ & $43.9 \%$ & $3.886^{* *}$ \\
\hline NR Alien & 48 & $42 \%$ & $5.9 \%$ & $-2.431^{*}$ & 28 & $50 \%$ & $0.8 \%$ & -0.966 \\
\hline Other & $\underline{30}$ & $\underline{53 \%}$ & $3.7 \%$ & $\underline{-0.293}$ & $\underline{90}$ & $44 \%$ & $\underline{2.7 \%}$ & -2.194 \\
\hline Total & 820 & $44 \%$ & $100.0 \%$ & $-7.432^{* *}$ & 3,341 & $55 \%$ & $100.0 \%$ & -2.287 \\
\hline
\end{tabular}

